\title{
RESEARCH ARTICLE \\ Flavonoids extracts from Psidium guajava, Vernonia amygdalina, and Azadiracta indica exhibited synergetic inhibitory activities against some food spoilage microorganisms
}

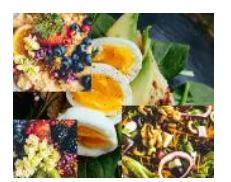

\author{
Iyanuloluwa Oluwajobi*, Adamu Y. Kabiru, Ali A. Jigam
}

Department of Biochemistry, School of Life Sciences, Federal University of Technology Minna, Nigeria

*Correspondence:

Iyanuoluwa Oluwajobi

iyanuloluwaoluwajobi@gmail.com

Received: 25 May 2021, Revised: 03 August 2021 Published: 17 August 202

\section{ABSTRACT}

Background: Flavonoids from medicinal plants have been reported to be a possible alternative to synthetic drugs due to their antimicrobial activities. In the present study, flavonoids extracts from the leaves of Psidium guajava, Vernonia amygdalina, and Azadiracta indica were evaluated for antibacterial and anti-fungi activities against some microbial isolates from spoiled tomato fruit. Methodology: Food spoilage microorganisms were isolated from spoiled tomato fruit. Flavonoids were isolated from the leaves of $P$. guajava, $V$. amygdalina, and $A$. indica, and were evaluated for their inhibitory activities against the isolated microorganisms using standard protocols. Results: The flavonoids extract demonstrated dose-dependent antimicrobial activities. Flavonoids extracts from $V$. amygdalina exhibited an inhibitory effect on $C$. tropicalis, $K$. pneumonaie, $M$. roseus, and $P$. aeruginosa with maximum inhibition diameters (MID) of $17.00 \pm 0.05,25.00 \pm 0.45,15.00 \pm 0.05$, and $16.00 \pm 0.34 \mathrm{~mm}$ while the flavonoids from $P$. guajava exhibited inhibitory effects on the same organism with MID of $15.00 \pm 0.05,14.00 \pm 0.10,16.00 \pm 0.55,15.00 \pm 0.43$ and $14.00 \pm 0.05 \mathrm{~mm}$ respectively, while the flavonoids extract from $A$. indica exhibited the least activity on the bacteria and fungi isolates. Results of the MICs and MBC revealed that the gram-positive bacteria tested ( $M$. roseus \& $S$. faecalis) were more susceptible to inhibition by the flavonoids extract of the plants. The combination of total flavonoids from leaves of $P$. guajava and $V$. amygdalina exhibited higher and synergetic antimicrobial activities against all the tested organisms when compared with individual flavonoids extracts. This combination could serve as a potential source of novel antimicrobial agents for food industry.

\section{Keywords: Flavonoids, Antimicrobial, A. indica; $P$. guajava; V. amygdalina; food spoilage organism}

Citation: Oluwajobi, I., Kabiru, Y. A., and Jigam, A. A. (2021). Flavonoids extracts from Psidium guajava, Vernonia amygdalina, and Azadiracta indica exhibited synergetic inhibitory activities against some food spoilage microorganism. AROC in Food and Nutritions, 1(1),15-21, https://doi.org/10.53858/arocfn01011521

\subsection{Introduction}

Flavonoids are a group of natural compounds in plants with variable phenolic structures [1]. They are present virtually in all parts of the plant and are responsible for the taste, color, protection of vitamins and enzymes, and prevention of fat oxidation [2]. The pharmacology importance of flavonoids, including, antioxidant, hepatoprotective, antibacterial, antiinflammatory, anticancer, and antiviral activities are indispensable in the human body $[2,3]$. Flavonoids displayed strong antimicrobial activity and inhibit several microorganisms, as they form complexes with cell wall components and adhesins to prevent microbial growth [4].

The guava (Psidium guajava) is a phytotherapeutic plant used in folk medicine that is believed to have active components that help to treat and manage various diseases [5]. The many parts of the plant have been used in traditional medicine to manage conditions like malaria, gastroenteritis, vomiting, diarrhea, dysentery wounds, ulcers, toothache, coughs, sore throat, and other infectious diseases [5].

Azadirachta indica, commonly known as the Neem tree belongs to the family Meliaceae. It is widely cultivated and well adapted in drier and humid ecological zones with an estimation of four million trees in the North-West Zone of Nigeria [6]. Traditionally, the neem is a very important medicine in Indian culture for the treatment of different ailments. It is one of the main sources of many therapeutic agents [7].

The bitter leaf (Vernonia amygdalina) has been ascertained to provide various culinary and medicinal properties, these medicinal properties exert bacteriostatic and bactericidal effects on some bacteria [8]. Antihelmitic, Antitumourigenic [9], and Antimalarial, [10] have also been reported for extracts from the plant. $V$. amygdalina possesses flavonoids including luteolin, luteolin 7-O- $\beta$-glucuronoside and 
lutelin7-O- $\beta$-glucoside [11]. The present study evaluated the anti-bacterial and anti-fungal activities of flavonoids extracts from $P$. guajava, A. indica, and $V$. amygdalina.

\subsection{Materials and Methods}

\subsection{Collection of plant}

The leaves of Veronia amygladina (bitter leaf), Azadirachta indica (Neem plant), Psidium Guajava (Guava leaves) were collected from Green farms in Niger State, Nigeria. Spoilt tomato fruits (Lycopersicum esculentum) were gotten from Kure market in Minna. All sample species were identified by a plant taxonomist at the Federal University of Technology, Minna. The plants were brought to the laboratory and rinsed with water to remove the soil particles. Then airdried at room temperature.

\subsection{Isolation of food spoilage microorganism}

Bacteria isolates including; Klebsiella pneumonaie, Pseudomonas aeruginosa, Microccocus roseus, and Streptococcus faecalis, and fungi including; Trichophyton tonsurans, Aspergillius niger, and Candida tropicalis were cultured and isolated from spoilt tomatoes fruit according to the methods described in previous studies [4].

\subsection{Isolation of Flavonoids:}

The leave samples were washed and dried for 2 weeks at $370 \mathrm{C}$, and ground using a grinder mill. A $50 \mathrm{~g}$ of the plant material was extracted with $200 \mathrm{~mL}$ of methanol, using soxhlet apparatus and the resulting extract was concentrated in a rotary evaporator. The methanol extract was dissolved in distilled water and extracted with n-butanol mixed with distilled water. The butanol extract was subjected to column chromatography on silica gel, eluted with $\mathrm{n}$-hexane and methanol according to the method described by Al-Jadidi and Hossain, [12].

\subsection{Antibacterial and anti-fungal Activity}

The plate-hole diffusion assay as described by Ieven et al. [13] was used to determine the zone of inhibition of bacteria (antibacterial activity) by the flavonoids extract of the plants. The selected microorganisms obtained were maintained at $4^{\circ} \mathrm{C}$ on nutrient agar plates before use. Using a sterile cork-borer of $5 \mathrm{~mm}$ diameter, five holes per plate were made into the set agar containing the bacteria culture. A total of 7 drops $(40 \mathrm{mg} / \mathrm{ml}, 80$ $\mathrm{mg} / \mathrm{ml}$, and $120 \mathrm{mg} / \mathrm{ml}$ ) of the flavonoids were poured into the wells, and one contained distilled water and ampicillin $(50 \mathrm{mg} / \mathrm{ml})$ as the negative and positive controls respectively. The plates were placed in the incubator at $37^{\circ} \mathrm{C}$ for $12 \mathrm{hrs}$. Antibacterial activity was recorded in millimeters $[14,15]$. This was also done for isolated fungi to know the antifungal activity of the extracts. Ampicillin was used as a standard for antibacterial assay, while vastatin was used as the standard for antifungal assay.

\subsection{Statistical analysis}

Values were analyzed using a statistical package for social science (SPSS) version 21 and presented as means $\pm \mathrm{SE}$ of the mean. Comparisons between different groups were carried out by oneway analysis of variance (ANOVA) followed by Duncan's Multiple Range Test (DMRT). The level of significance was set at $P<0.05$

\subsection{Results}

\subsection{Antimicrobial activities of flavonoids extract from $V$. amygdalina}

the flavonoids extract from $V$. amygdalina exhibited a dose-dependent inhibitory effect on $K$. pneumonaie, $M$. roseus, and Pseudomonas aeruginosa with maximum inhibition diameters of $25.00 \pm 0.45,15.00 \pm 0.05$ and $16.00 \pm 0.34 \mathrm{~mm}$ respectively (table 1 ). Antifungal activity of the flavonoids from $V$. amygdalina was observed only against Candida

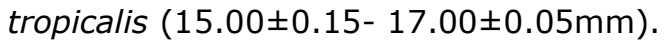

\subsection{Antimicrobial activities of flavonoids extract from $A$. indica}

The total flavonoids of $A$. indica exhibited antifungal activities against $A$. niger, $T$. tonsurans, and $C$. tropicalis only at higher concentrations of 80 and $120 \mathrm{mg} / \mathrm{ml}$. Similarly, the antibacterial activity of the flavonoids from $A$. indica was demonstrated against $M$. roseus $(15.00 \pm 0.15 \mathrm{~mm}) \quad$ and $S$. faecalis $(17.00 \pm 0.05 \mathrm{~mm})$ only at a higher dose of $120 \mathrm{mg} / \mathrm{mL}$ (Table 2). 
Table 1: Antimicrobial activities of total flavonoids from leaves of Vernonia amygdalina

\begin{tabular}{|c|c|c|c|c|c|}
\hline & \multicolumn{3}{|c|}{ Concentrations ( $\mathrm{mg} / \mathrm{mL})$} & \multicolumn{2}{|l|}{ Ampicillin } \\
\hline BACTERIA & 40 & 80 & 120 & 50 mg/ml & DMSO \\
\hline Klebsiella pneumonaie & $10.00 \pm 0.05$ & $12.00 \pm 0.10$ & $15.00 \pm 0.36$ & $25.00 \pm 0.45$ & - \\
\hline Microccocus roseus & $13.00 \pm 0.05$ & $14.00 \pm 0.87$ & $15.00 \pm 0.55$ & $15.00 \pm 0.25$ & - \\
\hline Streptococcus faecalis & - & - & - & - & - \\
\hline Pseudomonas aeruginosa & - & $13.00 \pm 0.55$ & $14.00 \pm 0.05$ & - & - \\
\hline FUNGI & 40 & 80 & 120 & $\begin{array}{l}\text { Vastatin } \\
(67 \mathrm{mg} / \mathrm{L})\end{array}$ & DMSO \\
\hline Aspergillius niger & - & - & - & $15.00 \pm 0.25$ & - \\
\hline Trichophyton tonsurans & - & - & - & $20.00 \pm 0.45$ & - \\
\hline Candida tropicalis & $15.00 \pm 0.15$ & $15.00 \pm 0.11$ & $17.00 \pm 0.05$ & - & - \\
\hline
\end{tabular}

Table 2: antimicrobial activities of total flavonoids from leaves of Azadirachta indica

\begin{tabular}{|c|c|c|c|c|c|}
\hline & \multicolumn{3}{|c|}{ Concentrations ( $\mathrm{mg} / \mathrm{mL}$ ) } & \multicolumn{2}{|l|}{ Ampicillin } \\
\hline BACTERIA & 40 & 80 & 120 & 50 mg/ml & DMSO \\
\hline Klebsiella pneumonaie & - & - & - & $25.00 \pm 0.45$ & - \\
\hline Microccocus roseus & - & - & $15.00 \pm 0.15$ & $15.00 \pm 0.25$ & - \\
\hline Streptococcus faecalis & - & - & $17.00 \pm 0.05$ & - & - \\
\hline Pseudomonas aeruginosa & - & - & - & - & - \\
\hline FUNGI & 40 & 80 & 120 & $\begin{array}{l}\text { Vastatin } \\
(67 \mathrm{mg} / \mathrm{L})\end{array}$ & DMSO \\
\hline Aspergillius niger & - & $14.00 \pm 0.15$ & $14.00 \pm 0.35$ & $15.00 \pm 0.25$ & - \\
\hline Trichophyton tonsurans & - & $15.00 \pm 0.25$ & $7.00 \pm 0.15$ & $20.00 \pm 0.45$ & - \\
\hline Candida tropicalis & - & - & $19.00 \pm 0.25$ & - & - \\
\hline
\end{tabular}

\subsection{Antimicrobial activities of flavonoids extract from $P$. guajava}

The total flavonoids of $P$. guajava exhibited a dose-dependent inhibitory effect on $K$. pneumonaie, $M$. roseus, $S$. faecalis, and $P$. aeruginosa with maximum inhibition diameters of $14.00 \pm 0.10,16.00 \pm 0.55,15.00 \pm 0.43$, and $14.00 \pm 0.05 \mathrm{~mm}$ respectively (table 3 ). Antifungal activity of the flavonoids from $P$. guajava was observed only against Candida tropicalis $(13.00 \pm 0.05-15.00 \pm 0.05 \mathrm{~mm})$.

3.4 Synergetic antimicrobial activities of flavonoids from leaves of $P$. guajava and $\boldsymbol{V}$. amygdalina

The combination of total flavonoids from leaves of Psidium guajava and Vernonia amygdalina at different ratios achieved synergetic antibacterial and antifungal activities against all the tested organisms in comparison with when the flavonoids from each plant were used singly (Table 4).

\subsection{Minimum inhibitory concentrations of the flavonoids of extracts on bacteria and fungi isolate}

The Minimum inhibitory concentrations (MICs) of the flavonoids extracts on the bacteria and fungi isolates are shown in table 5 while the minimum bactericidal concentration (MBC) and minimum fungicidal concentration (MFC) of the flavonoids extracts on the bacteria and fungi isolates are shown in table 6.

Table 3: antimicrobial activities of total flavonoids from leaves of Psidium guajava

\begin{tabular}{|c|c|c|c|c|c|}
\hline \multicolumn{4}{|c|}{ Concentrations ( $\mathrm{mg} / \mathrm{mL})$} & \multicolumn{2}{|l|}{ Ampicillin } \\
\hline BACTERIA & 40 & 80 & 120 & 50 mg/ml & DMSO \\
\hline Klebsiella pneumonaie & $9.00 \pm 0.56$ & $14.00 \pm 0.89$ & $14.00 \pm 0.10$ & $25.00 \pm 0.45$ & - \\
\hline Microccocus roseus & $14.00 \pm 0.35$ & $15.00 \pm 0.05$ & $16.00 \pm 0.55$ & $15.00 \pm 0.25$ & - \\
\hline Streptococcus faecalis & $7.00 \pm 0.55$ & $16.00 \pm 0.10$ & $15.00 \pm 0.43$ & - & - \\
\hline Pseudomonas aeruginosa & $10.00 \pm 0.15$ & $11.00 \pm 0.05$ & $14.00 \pm 0.05$ & - & - \\
\hline FUNGI & 40 & 80 & 120 & $\begin{array}{c}\text { Vastatin } \\
(67 \mathrm{mg} / \mathrm{L})\end{array}$ & DMSO \\
\hline Aspergillius niger & - & & & $15.00 \pm 0.25$ & - \\
\hline Trichophyton tonsurans & - & & & $20.00 \pm 0.45$ & - \\
\hline Candida tropicalis & $13.00 \pm 0.05$ & $15.00 \pm 0.05$ & $15.00 \pm 0.05$ & - & - \\
\hline
\end{tabular}


Table 4: Antimicrobial activities of combined total flavonoids from leaves of Psidium guajava and Vernonia amygdalina

\begin{tabular}{|c|c|c|c|c|c|}
\hline \multicolumn{6}{|c|}{ P guajava : V amygdalina } \\
\hline BACTERIA & $1: 1$ & $1: 2$ & 2:1 & 50 mg/ml & DMSO \\
\hline Klebsiella pneumonaie & $14.05 \pm 0.45$ & $10.05 \pm 0.03$ & $15.05 \pm 0.05$ & $25.00 \pm 0.45$ & - \\
\hline Microccocus roseus & $16.00 \pm 0.09$ & $15.03 \pm 0.56$ & $12.00 \pm 0.55$ & $15.00 \pm 0.25$ & - \\
\hline Streptococcus faecalis & $14.05 \pm 0.55$ & $8.05 \pm 0.56$ & $18.05 \pm 0.35$ & - & - \\
\hline $\begin{array}{l}\text { Pseudomonas } \\
\text { aeruginosa }\end{array}$ & $14.05 \pm 0.05$ & $12.00 \pm 0.55$ & $17.55 \pm 0.05$ & - & - \\
\hline FUNGI & 40 & 80 & 120 & $\begin{array}{l}\text { Vastatin } \\
(67 \mathrm{mg} / \mathrm{L})\end{array}$ & DMSO \\
\hline Aspergillius niger & $15.04 \pm 0.02$ & $13.06 \pm 0.64$ & $15.05 \pm 0.05$ & $15.00 \pm 0.25$ & - \\
\hline Trichophyton tonsurans & $17.30 \pm 0.25$ & $15.09 \pm 0.06$ & $12.55 \pm 0.55$ & $20.00 \pm 0.45$ & - \\
\hline Candida tropicalis & $19.55 \pm 0.06$ & $15.05 \pm 0.35$ & $17.50 \pm 0.35$ & - & - \\
\hline
\end{tabular}

\subsection{Discussion}

Flavonoids (derivatives of phenylchromone ring) are a large group of compounds naturally occurring in higher and lower plants. The inhibitory activities of flavonoids against bacteria and yeast have been investigated by a number of researchers [4,16-17). V. amygdalina serves as vegetables and is used as a nutritive seasoning in the preparation of food. Apart from its nutritive value, it has been found to be effective in inhibiting the growth of microorganisms. Researchers have also studied the phytochemical and antimicrobial properties of leaf and stem extract [8]. In the present study, the flavonoids extract from Vernonia amygdalina exhibited a dose-dependent inhibitory effect on Klebsiella pneumonaie, Microccocus roseus, and Pseudomonas aeruginosa with maximum inhibition diameters of $25.00 \pm 0.45,15.00 \pm 0.05$ and $16.00 \pm 0.34 \mathrm{~mm}$ respectively (Table 1 ). Antifungal activity of the flavonoids from Vernonia amygdalina was observed only against Candida tropicalis $(15.00 \pm 0.15-17.00 \pm 0.05 \mathrm{~mm})$. This finding is in agreement with earlier work by Udochukwu et al. [18] who reported the phytochemical and antibacterial activity of $V$. amygdalina. Streptococcus faecalis was observed to be completely resistant to all concentrations of flavonoids from $V$. amygdalina. This resistance may have arisen from drug/phytochemical inactivating enzymes present in Streptococcus faecalis. Also, variations observed in the susceptibility of Gram-positive and negative bacteria could have resulted from their relative composition of cell wall components.

Table 5: Minimum inhibitory concentration (MIC) of the flavonoids extracts on the bacteria and fungi isolate

\begin{tabular}{|c|c|c|c|c|c|}
\hline $\begin{array}{c}\text { P. guajava } \\
\text { (mg/mL) }\end{array}$ & 40 & $0.012 \pm 0.00$ & $0.002 \pm 0.00$ & & \\
& 80 & & $0.0014 \pm 0.00$ & & \\
\hline $\begin{array}{c}\text { A.indica } \\
\text { (mg/mL) }\end{array}$ & 120 & 80 & $0.0003072 \pm 0.00$ & & $0.003072 \pm 0.00$ \\
\hline $\begin{array}{c}\text { V. } \\
\text { amydalina }\end{array}$ & 80 & 0.00256 & & $0.002048 \pm 0.00$ & $0.002048 \pm 0.00$ \\
\hline $\mathbf{( m g / m L )}$ & 120 & & & & $0.002048 \pm 0.00$ \\
\hline
\end{tabular}

Table 6: Minimum bactericidal concentration (MBC) and minimum fungicidal concentration (MFC) of the flavonoids extracts on bacteria and fungi isolate

\begin{tabular}{|c|c|c|c|c|c|c|}
\hline & & M. roseus & S. faecalis & P. aeruginosa & T. tonsurans & C. tropicalis \\
\hline \multirow{3}{*}{$\begin{array}{c}\text { P. guajava } \\
(\mathrm{mg} / \mathrm{mL})\end{array}$} & 40 & $8.0 \pm 0.00$ & & & & \\
\hline & 80 & & $16.00 \pm 0.00$ & & & \\
\hline & 120 & & $24.00 \pm 0.00$ & & & $0.003072 \pm 0.00$ \\
\hline \multirow{2}{*}{$\begin{array}{l}\text { A.indica } \\
(\mathrm{mg} / \mathrm{mL})\end{array}$} & 40 & & $8.00 \pm 0.50$ & & & \\
\hline & 80 & & & & $0.0256 \pm 0.00$ & $0.002048 \pm 0.00$ \\
\hline \multirow{2}{*}{$\begin{array}{c}\text { V. } \\
\underset{(\mathrm{mg} / \mathrm{mL})}{\operatorname{amygdalina}}\end{array}$} & 80 & & & & & $0.002048 \pm 0.00$ \\
\hline & 120 & & & $24.00 \pm 1.50$ & & $0.003072 \pm 0.00$ \\
\hline
\end{tabular}


The total flavonoids of Azadirachta indica exhibited antifungal activities against $A$. niger, $T$. tonsurans, and $C$. tropicalis only at higher concentrations of 80 and $120 \mathrm{mg} / \mathrm{ml}$. Antibacterial activity of the flavonoids from $A$. indica was demonstrated against Microccocus roseus $(15.00 \pm 0.15 \mathrm{~mm})$ and Streptococcus faecalis $(17.00 \pm 0.05 \mathrm{~mm})$ only at a higher dose of $120 \mathrm{mg} / \mathrm{mL}$ (Table 2 ). This finding confirms the studies of Rao et al. [19], which reported that $A$. indica possesses a wide spectrum of antibacterial activities. Also, results obtained show that the extracts of the neem plant inhibited the growth of $C$. tropicalis as corroborated by the work of Khan and Wassilew [20]. The inhibition of various microbial isolates used in this study by the flavonoids extract from leaf of $A$. indica suggested it is effective in the treatment of infection caused by the organisms [21]. Candida spp has been implicated in thrush [22]

The total flavonoids of $P$. guajava exhibited a dose-dependent inhibitory effect on $K$. pneumonaie, $M$. roseus, $S$ faecalis, and $P$. aeruginosa with maximum inhibition diameters of $14.00 \pm 0.10,16.00 \pm 0.55,15.00 \pm 0.43$, and $14.00 \pm 0.05 \mathrm{~mm}$ respectively (table 3 ). Antifungal activity of the flavonoids from $P$. guajava was observed only against Candida tropicalis (13.00 $\pm 0.05-15.00 \pm 0.05 \mathrm{~mm})$. The observed dose-dependent inhibitory effects of the flavonoids extract against the bacteria and fungi correlate with the findings from the previous studies which reported that increasing concentration of antimicrobial substance led to corresponding increase growth inhibition of microorganisms [23-25]. Therefore, more of the antimicrobial agents were able to diffuse into the inoculated nutrient agar as the extract concentration increase.

The combination of total flavonoids from leaves of Psidium guajava and Vernonia amygdalina at different ratios achieved synergetic antibacterial and antifungal activities against all the tested organisms in comparison with when the flavonoids from each plant were used singly (Table 4 ).

The $40 \mathrm{mg} / \mathrm{ml}$ of the total flavonoids of $P$. guajava had a significantly higher MIC value (0.0128) on Micrococcus roseus while $120 \mathrm{mg} / \mathrm{ml}$ of the total flavonoids of $P$. guajava had a significantly lower MIC value $(0.0003072)$ on $S$. faecalis. For fungi, $120 \mathrm{mg} / \mathrm{ml}$ of total flavonoids of $P$. guajava had a significantly higher MIC value (0.003072) on C. tropicalis while $120 \mathrm{mg} / \mathrm{ml}$ of total flavonoids of $V$. amygdalina had a significantly lower MIC value (0.00153) on Candida tropicalis (table 5). Similarly, For bacteria, $40 \mathrm{mg} / \mathrm{ml}$ of the total flavonoids of P.guajava had higher MBC $(24 \mathrm{mg} / \mathrm{ml})$ on $S$. faecalis while $120 \mathrm{mg} / \mathrm{ml}$ of the total flavonoids of $V$. amygdalina had lower MBC value $(4 \mathrm{mg} / \mathrm{ml})$ on $P$. aeruginosa. For fungi, $120 \mathrm{mg} / \mathrm{ml}$ of total flavonoids of $P$. guajava had higher MFC value $(0.003072 \mathrm{mg} / \mathrm{ml})$ on C tropicalis while $120 \mathrm{mg} / \mathrm{ml}$ of total flavonoids of $V$. amygdalina had a lower MFC value $(0.00153 \mathrm{mg} / \mathrm{ml})$ on Candida tropicalis (table 6).

The lower range of MIC and MBC values of the flavonoids extracts from $P$. guajava, and $V$. amygdalina in this study translates to high antibacterial and anti-fungi potency on the extracts tested while the inhibitory activity is an indication of broad-spectrum activity against gram positive and gram negative bacteria [26] which implies that the phytochemical possessed broad-spectrum antibiotic compounds. However, based on the MBC values, flavonoids extract of $V$. amygdalina can be considered as a stronger anti bactericidal and anti-fungi agent compared with $P$. guajava, and $A$. indica. The results of the MICs and $\mathrm{MBC}$ revealed that the gram-positive bacteria tested were more susceptible to inhibition by the flavonoids extracts of the plants. The high inhibition of bacterial strains ( $M$. roseus \& $S$. faecalis) suggests that the flavonoids possesses higher spectrum antibacterial properties on gram +ve bacteria. Flavonoids are known to inhibit hydrolytic enzymes (proteases), microbial adhesion, and cell envelope transport proteins [27]. In addition, flavonoids form complexes with soluble and extracellular proteins of bacterial cell walls leading to their death [28].

\subsection{Conclusion}

The observed activity of the flavonoids extract from $A$. indica, $\quad P$. guajava and $V$. amygdalina against the tomatoes spoilage microorganism suggests the usefulness of the extracts in treating bacterial and fungal-based food infections. A combination of flavonoids from Psidium guajava and Vernonia amygdalina can serve as a potential source of novel antimicrobial agents for food industry.

\section{Authors' contributions}

This work was carried out in collaboration between all authors. Author OI designed the study and performed the experiment. Author AYK supervised the work and revised the thesis. Author AAJ Cosupervised the work. All authors read and approved the final thesis of this manuscript. 


\section{Funding}

No source of funding has been provided

\section{Competing Interests}

Authors have declared that no competing interests exist.

\section{References}

1. Özçelik, B., Orhan, DD, Özgen, S., \& Ergun, F. (2008). Antimicrobial activity of flavonoids against extended-spectrum $\beta$ lactamase producing (ESßL) Klebsiella pneumonia. Tropical Journal of Pharmaceutical Research, 7, 1151-1157

2. Yao, L. H., Jiang, Y. M., Shi, J., TomásBarberán, F. A., Datta, N., Singanusong, R. andChen, S. S. (2004). Flavonoids in Food and their Health Benefits. Plant Foods for Human Nutrition (Dordrecht, Netherlands).59(3): 113-122

3. Shashank, K. andAbhay, K. (2013). Chemistry and Biological Activities of Flavonoids: An Overview. The ScientificWorld Journal.4(2):32-48

4. Hernandez, N. E.; Tereschuk, M. L. and Abdala L. R. (2000), Antimicrobial activity of flavonoids in medicinal plants from Tafí del Valle (Tucumán, Argentina). $J$. Ethnopharmacol., 73, 317-322

5. Gutiérrez, R.M.P.; Mitchell, S.; Solis, R.V. Psidium guajava: A review of its traditional uses, phytochemistry and pharmacology. J. Ethnopharmacol. 2008, $117,1-27$

6. Anon. (2010). The Neem Tree. Retrieved from

http://www.Theneem.co.uk/actalog/TheN eemTree.html

7. Maragathavalli $S$, Brindha $S$, Kaviyarasi NS, Annadurai B,Gangwar SK. Antimicrobial activity in leaf extract of neem. IntJ Sci Nat 2012;3(1):110e3.

8. Evbuomwan, L; Chukwuka, Ep; Obazenu, E., Ilevbare, L. (2018). Antibacterial Activity of Vernonia amygdalina Leaf Extracts against Multidrug Resistant Bacterial Isolates. J. Appl. Sci. Environ. Manage. 22 (1) 17-21

9. Izevbigie, E.B., Bryant, J.L., Walker, A. 2004. A novel natural inhibitors of extracellular signal-regulated kinases and human breast cancer cell growth. Exp Biol Med. 229:163-169.

10. Abort, A.O., Raserika, B.H 2003. In vivo antimalarial activity of Vernoniaamygdalina.British Journal of Biomedical Science; 60:89-91

11. Igile, G. O., Wieslaw, O., Jurzysta, M., Stanislaw, B. and Fasanmade, A.(1994). Flavonoids from Vernonia amygdalina and their Antioxidant Activities. Journal of Agricultural and Food Chemistry.42:2445-2448.

12. Al-Jadidi, H.S.K., and Hossain, M.A. (2015). Studies on total phenolics, total flavonoids and antimicrobial activity from the leaves crudeextracts of neem traditionally used for the treatment of cough and nausea. Beni-suef university journal of basic and applied sciences 4 (2015) 93e98

13. Juven BJ, Kanner J, Schved $F$ and Weisslowicz H. (1994). Factors that interact with the antibacterial action of thyme essential oil and its active constituents. Journal of Applied Bacteriology, 76(6), 626-631.

14. Vlietinck $A J$, Van-Hoof $L$, Totté J, Lasure $A$ and Vanden BD. (1995). Screening of hundred Rwandese medicinal plants for antimicrobial and antiviral properties. Journal of Ethnopharmacology, 46, 31-47.

15. Yusuf AA, Lawal B, Yusuf MA, Omonije YO, Adejoke AA, Raji FH and Wenawo DL. (2018). Free Radical Scavenging Antimicrobial Activities and Effect of SubAcute Exposure to Nigerian Xylopia Aethiopica Seed Extract On Liver and Kidney Functional Indices of Albino Rat Iranian journal of toxicology ,12 (3), 5158

16. Umar SI, Lawal B, Mohammed BA, Obiekezie CI, Adewuyi AH, Babalola SB, Ariyeloye SD. Antioxidant and Antimicrobial Activities of Naturally Occurring Flavonoids from M. heterophylla and the Safety Evaluation in Wistar Rats. Iran J Toxicol. 2019;13(4):39-44

17. Fukai, T.; Marumo, A.; Kaitou, K.; Kanda T.; Terada, S. and Nomura, T. (2002), Antimicrobial activity of licorice flavonoids against methicillin-resistant 
Staphylococcus aureus. Fitoterapia, 73, 536-539

18. Udochukwu, U; Omeje, FI; Uloma, ISF; Oseiwe, D (2015). Phytochemical analysis of Vernonia amygdalina and Ocimum gratissimum extracts and their antibacterial activity on some drug resistant bacteria. Amer. J. Res. Communication 3(5): 225-235

19. Rao DVK, Sing K, Chopra R, Chatra PC,Ramanujalu G (1986). In vitroantibactericidal activity of neem oil. IndianJournal of Medicinal Research, 84: $314-316$

20. Khan M,Wassilar SW (1987). In natural pesticides from the Neem tree and other Tropical plants (eds Schmutterer, $\mathrm{H}$ and Asher, K. R.S.), GTZ., Eschborn, Germany pp.65

21. Itelima JU, Nwokedi VC, Ogbonna AI, Nyam MA (2016). Phytochemical screening and antimicrobial activity evaluation of aqueous and ethanolic extracts of the leaf of Azadirachta indica Juss(neem) on some microorganisms. World Journal of Microbiology, 3(1): 056060

22. Erique, G. (1988). Natural Remedies for Health and Well Being 5th Edition Orvit publishing Company, Mexico pp.359

23. Onukogu SC, Tsado AN, Muhammad FM, Alawode RA, Suleiman A, Ojo OP, Oshevire RM, Mustapha A, Lawal B. (2019). In Vitro Antioxidants, Antimicrobials and Biochemical Response of Methanol Leaf Extract of Eucalyptus camaldulensis following Sub-Acute Administration to Rats. Saudi J Biomed Res, 2019; 4(11): 405-411.DOI: 10.36348/SJBR. 2019.v04i11.007

24. Yusuf, A.A., Lawal, B., Abubakar, A.N., Berinyuy, E.B., Omonije, Y.O., Umar, S.I., Shebe, M.N., and Alhaji, Y.M. (2018). Invitro antioxidants, antimicrobial and toxicological evaluation of Nigerian Zingiber officinale. Clinical Phytoscience, $4,12,1-8$

25. Ibrahim, AM, Lawal, B, Abubakar, AN, Tsado, NA, Kontagora, GN, Gboke, GA, Berinyuy, EB. (2017). Antimicrobial and
Free Radical Scavenging Potentials of $\mathrm{N}$ Hexane and Ethyl Acetate Fractions of Phyllanthus Fraternus. Nigerian Journal of Basic and Applied Science, 25(2): 06-11. DOI:

http://dx.doi.org/10.4314/njbas.v25i2.2

26. Lawal, B., Shittu, O.K. Oibiokpa, I.F., Mohammed H, Umar, S.I., Haruna, G.M. (2016). Antimicrobial evaluation, acute and sub-acute toxicity studies of Allium sativum, Journal of Acute Disease 2016; 5(4): 296-301

27. Panche, $A N$, Diwan, $A D$, and Chandra SR. Flavonoids: an overview. Journal of Nutritional Science. 2016;5:e47. Doi: $10.1017 /$ jns. 2016.41

28. Wei L, Zhang W, Yin L, (2015). Extraction optimization of total triterpenoids from Jatropha curcas leaves using response surface methodology and evaluations of their antimicrobial and antioxidant capacities. Electron Journal of Biotechnology. 18:88-95.

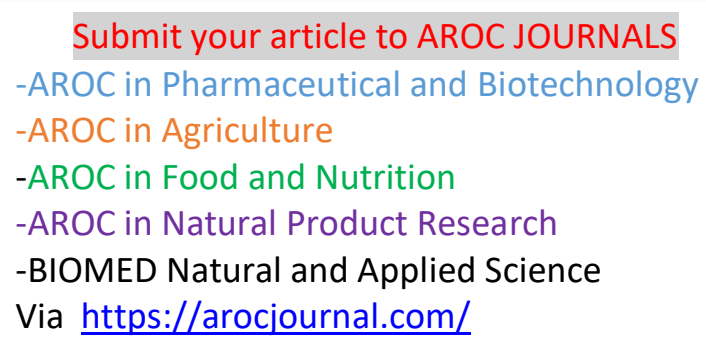

